\title{
Museum Origins: Readings in early museum history and philosophy
}

Ed. Hugh H. Genoways and Mary Anne Andrei

Walnut Creek, CA: Left Coast Press, 2008

344 pages

Reviewed by Beth Lord, University of Dundee

There have recently been a number of good collections of museum writing from the late twentieth century, reflecting the move to new models of museum display approaching the turn of the twenty-first century. Hugh H. Genoways and Mary Anne Andrei have now provided a much-needed collection from an earlier period of intensive museum development, the time of the move from curator-driven institutions to visitor-oriented museums around the turn of the twentieth century.

Museum Origins is a collection of museum writing largely from 1850 to 1920. The editors bring together 50 pieces, most of them published in journals and museum bulletins of the time, organized into seven sections. "Museum Origins" takes us from ancient and early modern writings on museum up to a late nineteenth-century survey of their development. "Museum Philosophy” and "The New Museum” offer pieces considering the purpose, functions, and value of museums, showing how public education came to be the key museum idea towards the turn of the century. "Museum Education" continues that theme, revealing the thinking and planning behind early museum education programmes. "Museum Exhibition" presents debates concerning how the display of objects in natural history and ethnographic collections can most effectively educate and interest the public. A section on "Museums and Universities" contains reflections about campus museums and their educative and research roles. A final section on "Philosophy of Museums with Living Collections" considers topics specific to zoos and gardens. Pieces that stand out include William Stanley Jevons's and George Brown Goode's manifestos on the "new museum"; Anna Billings Gallup, early curator of the Brooklyn Children's Museum, on museums' role in educating children beyond school walls; Franz Boas and George Dorsey on systematic versus contextual exhibitions of ethnographic objects; John George Wood on "The Dulness of Museums” [sic], and Edwin Godkin denouncing P.T. Barnum's American Museum for amusing the lower classes without edifying them.

Reading these pieces shows us that the problems museums face today are, in many ways, those of the turn of the twentieth century. The articles by Boas and Dorsey illuminate an ongoing debate on whether displays should be systematic and focus on the intrinsic quality, interest, and classification of objects, or contextual and focus on the broader historical and cultural narratives into which objects fit. The emergence of the "new museum" in the late nineteenth century, with the development of an exhibition style attractive not just to scholars but also to the visiting public, involved the move to more contextual displays. Now that there is a trend for de-contextualizing museum objects, we might well learn from these earlier debates, while remaining critically aware of the ideologies that sometimes underpinned them. In many articles, a genuine belief in the power of education to transform lives - often championed by women - is balanced by condescension towards "working men”, immigrants, and others believed to be in need of edification by public institutions. The history of the idea that museums improve the 
morality, refinement, and national identity of the masses, familiar from the work of Tony Bennett, is well documented by many of the selections in Museum Origins. Most interesting is the article by Brooklyn Children's Museum curator Anna Billings Gallup on the activities of this pioneering institution. It is her careful assessment of the power of museums to enhance all aspects of children's lives, and not the sweeping demands that museums should educate the masses "whether they will or no" (53), that is most influential today.

The question of what a museum is, is also well treated in this book, as several authors consider the distinction between museum and non-museum. Edwin Lawrence Godkin's 1865 article, "A Word About Museums", takes the occasion of the destruction of P.T. Barnum's American Museum by fire to consider the differences between the museum and the theme park. Barnum's museum "pandered to the most foolish curiosity and to the most morbid appetite for the marvelous" (35), and had no intent to educate. The museum's serious purpose, however, must be balanced by displays that engage the public, as John George Wood writes in 1887. The main problem with museums is their dullness: "Full of interest to the expert, there is no concealing the fact that to the general public a museum, of whatever nature, is most intolerably dull. ... Stones, bones, and fossil shells, plants, and animals leave no further impression on the mind of the general visitor than that some are very big, and all of them are very ugly" (217-8). There are interesting indicators too of the museum's future progress. In the words of Frederic Lucas, director of the Brooklyn Museum in 1907, the old museum was merely a storehouse for displaying objects, whereas the new "aims to illustrate ideas" (59). The foundation was set for the "idea museums" of the late twentieth century.

There is much in Museum Origins that is intriguing and illuminating. The best pieces in this collection are, however, padded with other texts that are neither singular nor outstanding examples of museum literature. Many of the pieces presented are, frankly, mediocre and repetitive, when what is wanted is a collection in which every piece is exemplary of something new and different. Such a collection would not have been difficult to achieve, had the editors not restricted their remit to such a narrow geographical and linguistic range. With the exception of two short texts from antiquity, the pieces were written exclusively in English, and the majority are American. This gives the book's content a much narrower scope than its title portends: Readings in Early Museum History and Philosophy suggests a range of writings concerning early museums, the most important of which are in Europe. While the major British museums are represented here, those of Paris and Berlin - about which some of the world's best and most important museum texts have been written - are curiously absent. Readers interested in the history of the museum in a European or global context will find little to interest them here. But the focus on American museum history does not really explain this editorial decision, since even readers interested in American museum history would benefit from the rich museum literature written in France, Germany, and Italy in the nineteenth and early twentieth centuries (to which many of the featured, American, authors allude).

Another problem is the casual use of the word "philosophy" to describe some of the texts in this collection. There is a tendency to use the term 'philosophy' wherever any "why" questions arise, but a piece of writing is not philosophy just by virtue of reflecting on the definition and purpose of something; it must make use of philosophical arguments, 
methods, traditions, or thinkers. While many of the pieces in this book address the questions "what is a museum?" and "what are museums for?", none of them is philosophical because none of them deploys philosophical resources to answer these questions. That does not devalue them as pieces of museum writing, but it does make it misleading to label them "philosophy". For example, a piece on "Museum ethics" by L. Earle Rowe boils down to policy questions about loaning objects between institutions; though it gestures towards ethical issues of friendship and obligation, its concern is wholly practical. In fact, nearly all the texts in this collection are pragmatic pieces aimed at concrete problem-solving. Some literary, reflective, and genuinely philosophical pieces would have been welcome: Proust's reflection on the art gallery promenade in A la recherche du temps perdu, or Hegel's comments on the "death" of the artwork in the museum in his Aesthetics, for instance. Instead, the history of museum development is presented as parochial and pragmatic, rather than visionary or genuinely philosophical. The discipline of museum studies could use a good collection of the most significant pieces of museum writing and museum thinking from the seventeenth to the early twentieth century. This book is not it. Museum Origins is, instead, a book documenting the history of American museums and heritage institutions at a key stage of their development. There is nothing wrong with that, but perhaps it would more accurately be subtitled "Readings in the History and Practice of the American Museum". As such, it is a worthwhile collection with much to interest the museum professional, the academic, and the museum visitor. 